\title{
Presentación de un caso de quiste dermoide con ubicación poco frecuente
}

\author{
Presentation of a dermoid cyst case with an unusual location
}

\author{
A. Ostrosky' , R. Luberti ${ }^{4}$, E. Mareso², J. Klurfan Federico 3
}

Resumen: El quiste dermoide es una patología benigna de origen embrionario y su localización en el piso de la boca es poco frecuente. No presenta predilección por sexo y aparece, especialmente, entre la segunda y la tercera década de vida. Para su diagnóstico son útiles las tomografías computadas y las resonancias nucleares magnéticas. El tratamiento es quirúrgico. Tanto las recidivas como la transformación maligna son excepcionales.

Palabras clave: Quiste dermoide; Quiste teratogénico; Quiste epidermoide.

Recibido: 08-01-2003

Aceptado: 06-10-2004

\section{Introducción}

El quiste dermoide es una patología originada en las células epiteliales atrapadas durante el cierre o fusión de los procesos embrionarios que forman el piso de la boca. ${ }^{1-2}$

De acuerdo a la sugerencia realizada por Baker en 1883, se lo clasifica en quiste dermoide medial o de la línea media y quiste dermoide lateral, que puede afectar uno o excepcionalmente ambos lados. ${ }^{3}$

Otros autores lo han dividido en relación con el músculo genihioideo; aquellos que se hallan por debajo del mismo (posi-

1 Jefe del Servicio de Cirugía Maxilofacia

2 Jefe del Servicio de Anatomía Patológica

3 Residente del Servicio de Cirugía Maxilofacial

Hospital Mariano y Luciano de la Vega, Moreno, Provincia de Buenos Aires, Argentina

4 Profesor Titular de la Cátedra de Radiología de la Facultad de Odontología, Universidad de Buenos Aires, Buenos Aires, Argentina

Correspondencia:

Dr. Federico Juan Klurfan

Av. Santa Fe $12032^{\circ}$ Piso

C1059ABG Buenos Aires, Argentina

Email: fklurfan@hotmail.com
Abstract: The Dermoid Cyst is a benign pathology of embrionary origin and its localization in the floor of the mouth is not very frequent. With no preference for sex, it appears especially between the second and third decades of life. Computed scans and magnetic nuclear reso-nances are useful for its diagnosis. The treatment is surgical and recurrences, as well as malignant transformation, are exceptional.

Key words: Dermoid cyst; Teratogenic cyst; Epidermoid cyst.

\section{Introduction}

The dermoid cyst is a pathology that originates in the epithelial cells that become trapped during the closure or fusion of the embryonic processes that form the floor of the mouth. 1,2

According to Baker's suggestion put forward in 1883, it is classified as a medial dermoid cyst or of the midline, and lateral dermoid cyst, when it affects one or exceptionally both sides. ${ }^{3}$

Other authors have divided it according to the geniohyoid muscle; those found under it (in the submental region) and those found above it (in the sublingual region). ${ }^{3}$

The dermoid cyst shows no sex predilection. With regard to age, it appears particularly during the second and third decades of life. ${ }^{4}$ Shafer and col. ${ }^{5}$ claim that, unlike dermoid cysts observed in other parts of the body, those found on the floor of the mouth at birth are reported very sporadically. Nevertheless there are interesting cases registered in neonatal infants. 6,7

Various authors claim that the lesion when related to the mouth appears to exist at birth, but that generally it is clinically identified in young people. 
ción submental) y los que se encuentran por encima (posición sublingual). ${ }^{3}$

El quiste dermoide no presenta supremacía sexual. Con referencia a la edad, se observa especialmente durante la segunda y tercera décadas de vida. ${ }^{4}$ Shafer y cols. ${ }^{5}$ sostienen que, a diferencia de quistes dermoides observados en otras partes del cuerpo, los que se encuentran en el piso de la boca, se registran muy esporádicamente en el momento del nacimiento. No obstante ello hay interesantes casos registrados en recién nacidos. 6,7

Diversos autores sostienen que la lesión al nivel de la boca parece existir en el nacimiento, pero se identifica clínicamente por lo general en personas jóvenes.

Clínicamente, se presenta como una masa móvil a la palpación, de características fluctuantes y en ocasiones, de consistencia pastosa. El crecimiento es

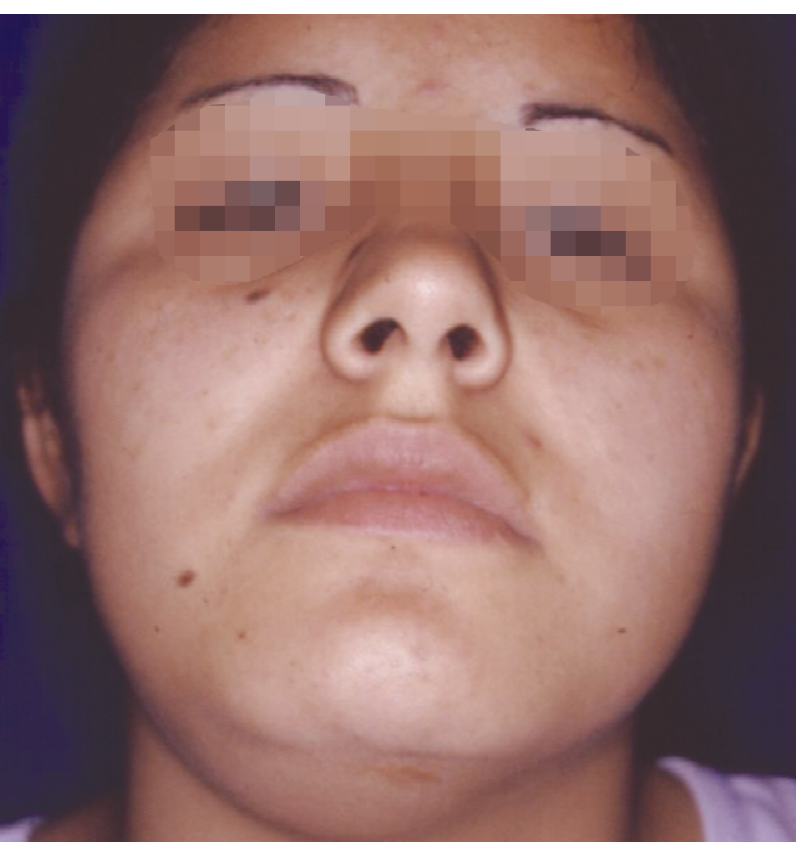

Figura 1. Imagen preoperatoria del paciente. Figure 1. Preoperative image of the patient.
Clinically it appears as a movable mass on palpation, with fluctuating characteristics and occasionally with a pasty consistency. Generally it grows slowly and it is painless. When located above the geniohyoid muscle it tends to raise the tongue leading to difficulties in phonation, swallowing and even respiratory problems.

Unlike the thyroglossal cyst, the dermoid cyst does not move when the tongue is extended. 8,9 The mucosa, skin and salivary fluid of the adjoining glands are nearly always normal, showing no adenopathies.

As this is a soft tissue entity, conventional radiographic examination is not very lento y por lo general indoloro. Cuando se localiza por encima del músculo genihioideo suele elevar la lengua originando dificultades en la fonación, en la deglución e incluso problemas en la respiración.

A diferencia de los quistes del conducto tirogloso, los quistes dermoides no se desplazan con la protrusión de la lengua. ${ }^{8,9} \mathrm{La}$ mucosa, la piel y el flujo de la saliva de las glándulas aledañas son casi siempre normales, sin la presencia de adenopatías.

Por tratarse de una entidad ubicada en los tejidos blandos, el examen radiográfico convencional es poco demostrativo. Antes del advenimiento de la tomografía computada y la imagen por resonancia magnética se procedía a eliminar el contenido líquido del quiste y a colocar un medio de contraste con el objeto de conocer radiográficamente su forma, límite, tamaño y relación con estructuras anatómicas vecinas. ${ }^{10}$

La anatomía patológica resulta fundamental en el diagnóstico final. El revestimiento del quiste dermoide es un epitelio escamoso estratificado queratinizado que contiene uno o varios anexos cutáneos como por ejemplo folículos pilosos, glándulas sudoríparas y sebáceas. La falta de estos elementos dificulta el diagnóstico. Otras variantes histológicas del quiste en descripción son el tipo epidermoide y el tipo teratoide. ${ }^{11}$

El tratamiento es quirúrgico $y$, una vez extirpado, no recidiva salvo excepciones.

\section{Caso clínico}

En Marzo de 2002 se presentó a nuestro servicio un a paciente de sexo femenino, de 26 años de edad, con una tumoración consistente, indolora, no adherida a los planos profundos. Presentaba dos años de evolución y hacía relieve tanto en la región demonstrative. Before the advent of computed tomography and magnetic resonance imaging, the liquid content of the cyst was eliminated and a contrast medium was administered in order to determine radiographically the shape, edges, size and relationship with neighboring anatomical structures. ${ }^{10}$

Its pathological anatomy is fundamental for the final diagnosis. The surface of the dermoid cyst consists of a keratinized stratified squamous epithelium, which contains one or various skin appendages such as hair follicles, sudoriparous and sebaceous glands. If these elements are not present, diagnosis is more difficult. Other histological variations of the cyst described are of the epidermoid and teratoid type. ${ }^{11}$

Treatment is by means of surgery and, once removed, it does not recur bar a few exceptions.

\section{Clinical case}

In March 2002 a 26 year-old female patient was presented to our service with a solid tumor-like [mass], which was painless and had not extended into the deeper layers. It had been evolving for two years and was creating a bulge in the submental area as well as in the floor of the mouth (Fig. 1). The patient had no personal or family history of relevance.

In order to complete the study of the patient, fine needle aspiration (FNA) was carried out, and a sample was sent to the service of Pathological Anatomy. The computed tomography also requested showed the location of the lesion in the floor of the mouth, its considerable size and its well-defined margins (Fig. 2). 
submentoniana como en el piso de boca (Fig. 1). La paciente no presentaba antecedentes personales ni hereditarios de relevancia.

A modo de completar el estudio de la paciente, se realizó una punción con aguja fina (PAF) y se envió la muestra al Servicio de Anatomía Patológica. Se indicó además, una tomografía computada donde se pudo observar la ubicación de la lesión en el piso de boca, su gran tamaño y sus límites bien nítidos (Fig. 2).

Teniendo la confirmación diagnóstica por parte del Servicio de Anatomía Patológica, se indica la extirpación quirúrgica de la lesión. Bajo anestesia general y mediante una incisión horizontal en la región anterior de cuello a nivel del pliegue cutáneo, se obtuvo acceso a la lesión (Fig. 3).

La pieza extirpada era una formación quística bien delimitada de $3 \mathrm{~cm}$ de diámetro que a su apertura contenía material pastoso blanco amarillento (Fig. 4).

El examen microscópico reveló una pared quística revestida por un epitelio escamoso estratificado queratinizado con glándulas sebáceas. La misma presentaba una solución de continuidad revestida por un granuloma constituido por linfocitos, plasmocitos, histiocitos y células gigantes de tipo cuerpo extraño (Fig. 5).

La recuperación postoperatoria de la paciente fue muy satisfactoria y no se han detectado recidivas luego de 1 año de seguimiento (Fig. 6).

\section{Discusión}

El área de cabeza y cuello no constituye una ubicación preferencial de la entidad en descripción, tal como lo demuestra una de las más grandes revisiones efectuadas por New y Erich. ${ }^{12}$ De 1.495 quistes dermoides estudiados durante 25 años en la clínica Mayo observaron que sólo el 6,9\% (103 casos) se ubicaban en

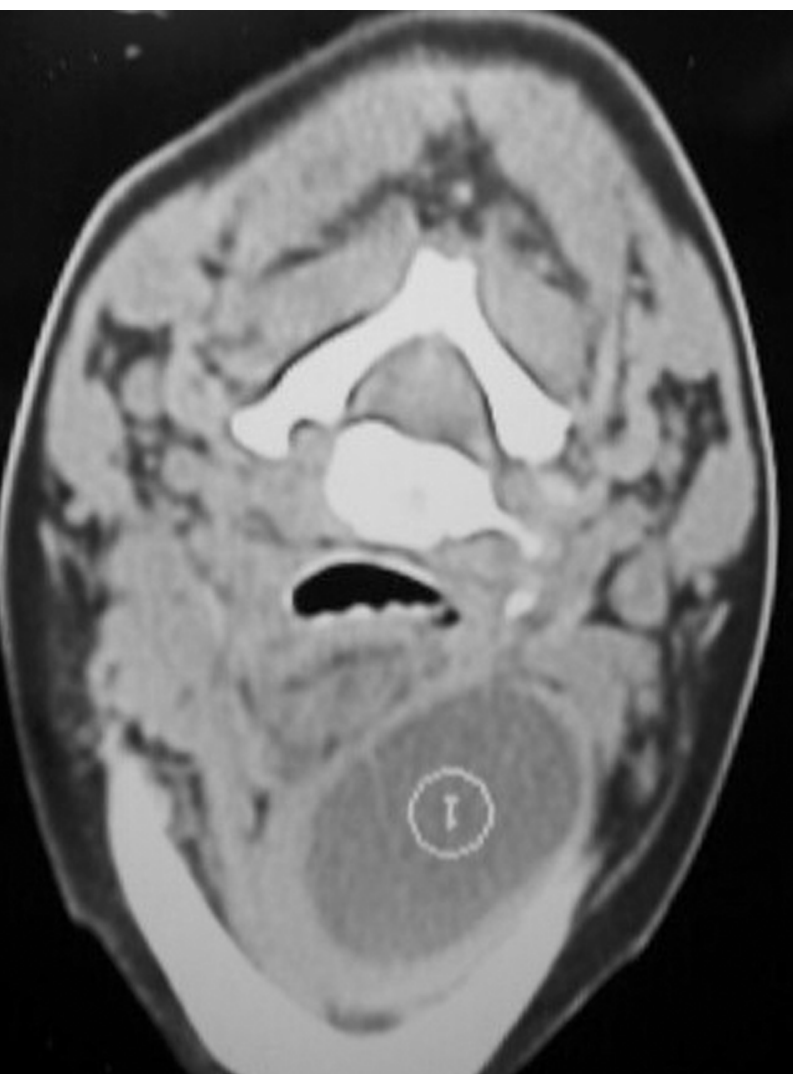

Figura 2. Tomografía Computada donde se observa nítidamente la lesión.

Figure 2. Computed Tomography in which the lesion is clearly visible

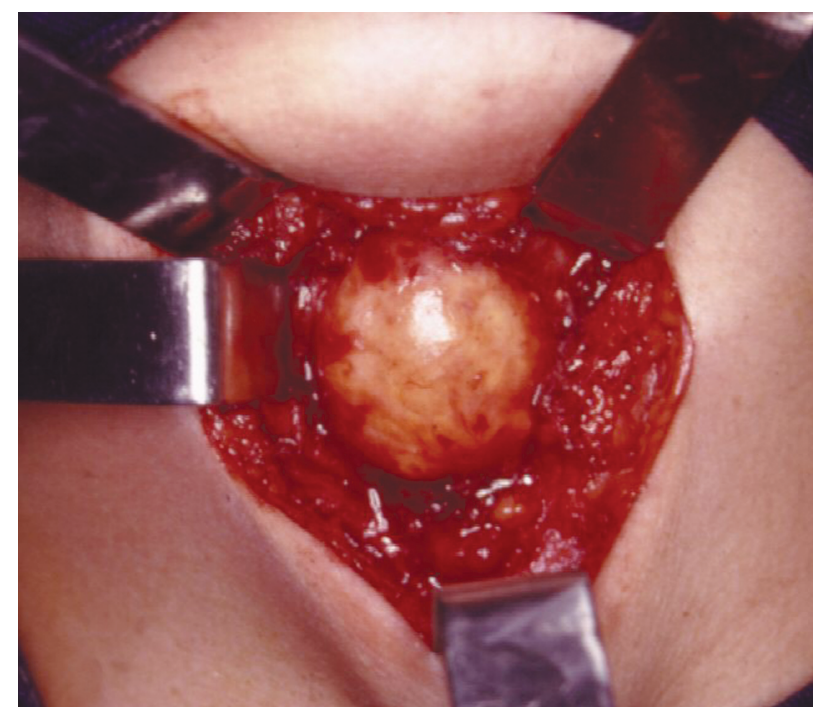

Figura 3. Imagen intraoperatoria. Figure 3. Intraoperative image.
With the diagnosis confirmed by the Service of Pathological Anatomy, surgical excision of the lesion was recommended. Under general anesthesia the lesion was accessed by means of a horizontal incision in the anterior region of the neck at the same level of the crease in the skin (Fig. 3). The sample removed had a well-defined cystic formation with a diameter of $3 \mathrm{~cm}$ which, following incision, contained a yellowy white pasty material (Fig. 4).

On microscopic examination a cystic wall was observed, which had a keratinized stratified squamous epithelium with sebaceous glands. It had a break in continuity and was covered with a granuloma that consisted of lymphocytes, plasmocytes, histiocytes and giant cells of a strange body type (Fig. 5).

The postoperative recuperation of the patient was very satisfactory and during the following year no recurrence was detected (Fig. 6).

\section{Discussion}

The area of the head and neck is not a preferential location of the entity described, as is demonstrated by one of the largest reviews carried out by New and Erich. ${ }^{12}$ Of 1495 dermoid cysts studied during 25 years in the Mayo clinic they observed that only $6.9 \%$ (103 cases) were located in this area, and that 1.6\% (24 cases) of all dermoid cysts were located in the floor of the mouth.

Cases have been described in totalidad de los quistes dermoides, se localizaban en el piso de la boca.

Se han descrito casos en la región nasal, sinusal y orbitaria, en el cuero cabelludo, recto, ovario, abdomen, testículo, glándulas sali- the region of the nose, sinuses, orbits, scalp, rectum, ovaries, abdomen, testicles, salivary glands, spinal cord, brain etc. ${ }^{13-17}$

Exceptionally cases have been reported in the maxillary region. Worth ${ }^{18}$ recounts the case of a dermoid cyst locat- 
vales, médula espinal, cerebro, etc. ${ }^{13-17}$ Excepcionalmente se citan casos a nivel del maxilar. Worth, ${ }^{18}$ narra un caso de quiste dermoide ubicado en el maxilar inferior de un hombre de 40 años, con aspecto radiográfico de quiste de naturaleza odontogénica.

En base a una reseña estadística realizada en nuestro servicio, corroboramos la relación 1:1 en cuanto a la prevalencia sexual de esta lesión, que se presenta en individuos jóvenes entre 15 y 45 años de edad.

La transformación maligna de la lesión es excepcional y se han descrito pocos casos. ${ }^{19,20}$

Según Meyer, ${ }^{3}$ el diagnóstico diferencial desde el punto de vista clínico deberá realizarse con las siguientes entidades: 1) ránula; 2) quiste del conducto tirogloso; 3) higroma quístico; 4) quiste de la hendidura branquial; 5) infecciones agudas y celulitis del piso de boca; 6) infecciones de las glándulas submaxilar y sublingual; 7) tumores benignos y malignos del piso de la boca; 8 ) masas adiposas del área submentoniana.

La sialoadenografía de la glándula submaxilar ha sido utilizada para efectuar el diagnóstico diferencial entre lesiones intraglandulares y quistes de áreas aledañas. Seward, ${ }^{10}$ presenta un estudio contrastado con notoria elevación del conducto de Wharton, producto de un quiste dermoide ubicado en el piso bucal. La ultrasonografía y la punción con aguja fina (PAF) también han sido utilizadas con fines diagnósticos. En nuestro caso, la PAF fue de gran utilidad en el diagnóstico diferencial, aunque el diagnóstico certero se obtuvo con la biopsia postoperatoria.

La tomografía computada prácticamente ha reemplazado a la radiografía convencional y suele ser utilizada en el estudio del quiste dermoide. ${ }^{21,22}$ Proporciona una imagen hipodensa (alrededor de -35 a -84 UH) que corresponde al contenido graso. Esta sustancia producida por las glándulas sebáceas diferencia los quistes dermoides de otras masas con densidades similares. Cuando no se pone en evidencia, suele ser dificultoso establecer el diagnóstico sobre la base de ese procedimiento. Otros investigadores utilizan la RM, especialmente, en localizaciones cerebrales y orbitarias. ${ }^{23,24}$ Este procedimiento muestra en forma excelente la estructura interna, límites, tamaño, forma y la relación con estructuras anatómicas del quiste dermoide.

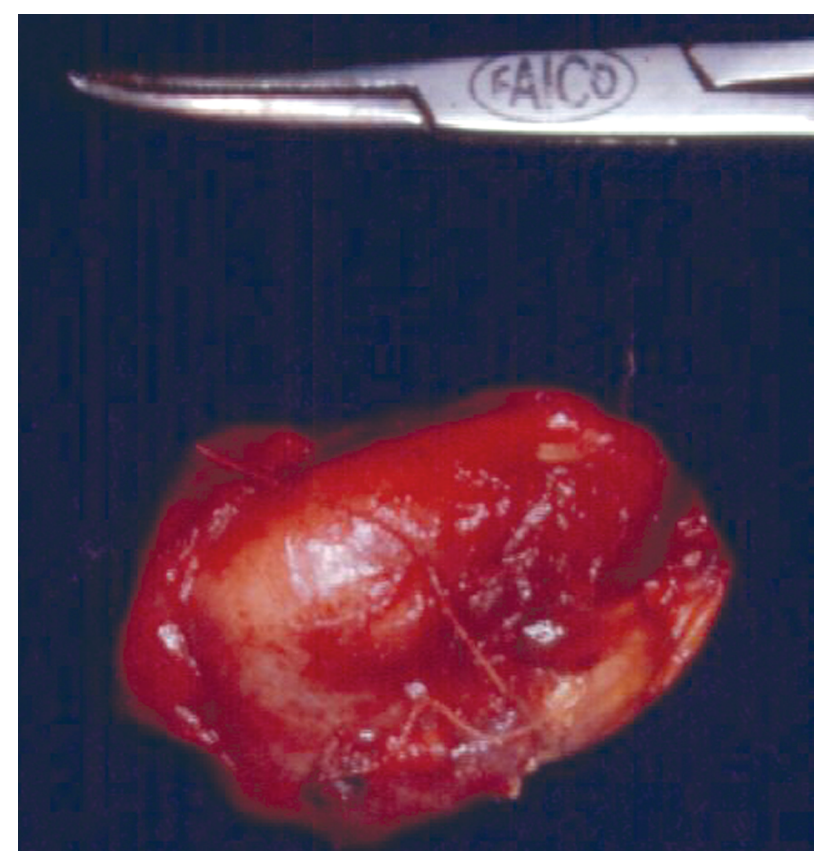

ed in the lower maxilla of a 40-year-old man that appeared radiologically to be a cyst of odontogenic origin.

In a statistical revue carried out in our service, a ratio of 1:1 was corroborated with regard to the sex predilection of this lesion that appears in young individuals between the ages of 15 and 45.

The malignant transformation of the lesion is exceptional, and few cases have been described. ${ }^{19,20}$ According to Meyer ${ }^{3}$ the differential diagnosis from the clinical point of view should be carried out with the following entities. 1) ranula; 2) cyst of the thyroglossal duct; 3 ) cystic hygroma; 4) branchial cleft cysts; 5) acute infections and cellulitis of the floor of the mouth; 6) infections of the submaxillary and sublingual glands; 7) benign and malignant tumors of the floor of the mouth; 8) adipose masses in the submental area.

The sialadenography of the submaxillary grand has been used for making the differential diagnosis between intraglandular lesions and cysts in the surrounding area. Seward ${ }^{10}$ presents a contrasted study with an obvious elevation of Wharton's duct, as a result of a dermoid cyst located in the floor of the mouth. Ultrasound and fine needle aspiration (FNA) have also been used for diagnostic purposes. In our case, the FNA was particularly useful in the differential diagnosis, although the exact diagnosis was obtained by means of a postoperative biopsy.

Computed tomography has practically replaced conventional radiography and it tends to be used in the investigation of the dermoid cyst.21,22 Hypodense images are depicted (around -35 to -84 HU) corresponding with the fat content. This substance, which is produced by sebaceous glands, differentiates 
Nosotros no hemos evidenciado recidivas en los quistes dermoides operados en el servicio, sin embargo, Bleninsopp y Rowe, ${ }^{25}$ presentan un caso de recurrencia en una mujer de 31 años, con un quiste dermoide en el piso de boca operado 13 años antes.

\section{Conclusiones}

De acuerdo a nuestra experiencia, siempre realizamos como primer paso para la confirmación diagnóstica la punción con aguja fina (PAF) e indicamos la tomografía computada como estudio por imágenes. También hemos utilizado la resonancia nuclear magnética con muy

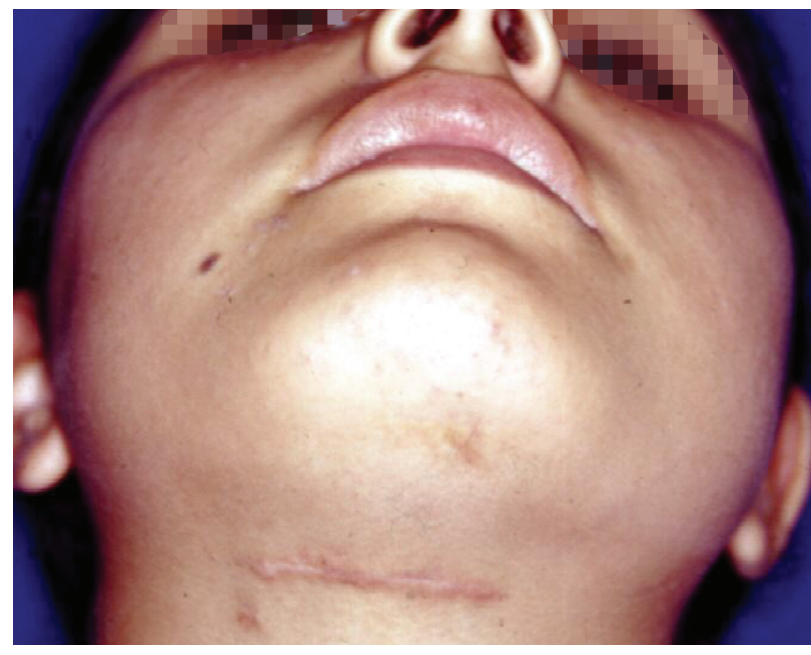

Figura 6. Imagen postoperatoria. Figure 6. Postoperative image. buenos resultados.

Coincidimos con los autores consultados en la baja incidencia de la lesión en el piso de la boca y en que no se observan recidivas luego de su tratamiento quirúrgico.

\section{Bibliografía}

1. Eversole L. Patología Bucal. 1a ed. Editorial Panamericana. Buenos Aires $1983 ; 112$.

2. Zegarelli E, Kutscher A, Hyman G. Diagnóstico en Patología Oral. 2ª ed. Editorial Salvat. Barcelona 1982;238.

3. Meyer I. Dermoid Cysts (dermoids) of the floor of the mouth. Oral Surg 1955;8:1149.

4. Som P, Bergeron R. Radiología de Cabeza y Cuello. 2aㅡ ed. Editorial Mosby-Year Book. Madrid 1993;544.

5. Shafer W, Hine M, Levy B. Tratado de Patología Bucal. Editorial Interamericana. 3a ed. México 1977;76.

6. Bloom D, Carvalho D, Edmonds J, Magit A. Neonatal dermoid cyst of the floor of the mouth extendinsg to the midline neck. Arch Otolaryngol Head Neck Surg 2002; 128:68.

7. Gibson W, Fenton N. Congenital sublingual dermoid cyst. Arch Otolaryngol 1982;108:745.

8. Fitzpatrick T, Eisen A, Wolff K, Fredberg I, Austen K. Dermatology in General Medicine. Vol I Editorial Mc Graw-Hill. Fourth ed. New York 1993;869.

9. Brown J, Morokoff A, Mitchell P, González M. Unusual imaging appearance of an intracranial dermoid cyst. AJNR 2001;22:1970.

10. Seward H. Dermoid cysts of the floor of the mouth. Br J Oral Surg 1965;3:36.

11. Brown J, Morokoff A, Mitchell P, González M. Unusual imaging appearance of an intracranial dermoid cyst. AJNR 2001;22:1970.

12. New G, Erich J. Dermoid cyst of the head and neck. Surg Gynecol Obstet 1937;65:48.

13. Loke D, Woolford T. Open septorhinoplasty approach for the excisión of a dermoid cyst and sinus with primary dorsal reconstruction. J Laringol Otol 2001;115:657.

14. Amir R, Dunham M. Bilateral choanal atresia associated with nasal dermoid cyst and sinus. Int J Pediatr Otorhinolaryngol 2001;58:81. dermoid cysts from other masses with similar densities. When this is not clear, establishing the diagnosis is usually difficult on the basis of this procedure. Other investigators use NMR, especially in cerebral and orbital localizations.23,24 This procedure is an excellent way of displaying the internal structures, edges, size, shape and relationship with the anatomical structures of the dermoid cyst.

We have not observed any recurrence of the dermoid cysts operated on in our service. Bleninsopp and Rowe, ${ }^{25}$ however present a case of recurrence in a 31 year old with a dermoid cyst of the floor of the mouth that had been operated on 13 years previously.

\section{Conclusions}

In our experience, we always carry out a FNA as a first step in order to obtain diagnostic confirmation and, with regard to imaging studies, we request a CT scan. We have also used nuclear magnetic resonance with very good results.

We agree with the authors consulted in the low incidence of the lesion in the floor of the mouth, and that following surgical treatment recurrence is not observed. 
15. Torske K, Benson G, Warnock G. Dermoid cyst of the maxillary sinus. Ann Diagn Pathol 2001;5:172.

16. Sakurai $Y$, Uraguchi T, Imazu H, Hsegawa S, Matsubara T, Ochiai M, Funabiki T. Submucosal dermoid cyst of the rectum. Surg Today 2000;30:195.

17. Ulbright T, Srigley J. Dermoid cyst of the testicle. Am J Surg Pathol 2001;25:788.

18. Worth H. Principles and Practice of Oral Radiologic Interpretation. 1․ ed. Editorial Year-Book. Chicago 1963;473.

19. Tsugu H, Fukushima T, Hagashi S. Squamous cell carcinoma arising in a intracranial dermoid cyst. Neurol Med Chir (Tokyo) 2001;41: 213.
20. Devine J, Jones D. Carcinomatous transformation of a sublingual dermoid cysts. Int J Oral Maxilofac Surg 2000;29:126.

21. Bilaniuk $L$, Rapoport J. Magnetic resonance imaging of the orbit. Topic Magnetic Resonance Imaging 1994;6:1673.

22. Hunter T, Paplanus S, Chermin M, Coulthard W. Dermoid cyst of the flooor of the mouth CT appearance. AJR 1983;141:1239.

23. Lee J, Stanley R, Sagel S, Heiken J. Body TC correlation RM. Editorial Marban. Vol. 1 3a ed Madrid 1999;164.

24. Zeltzer R, Milhen I, Araz B, Hasson O. Dermoid cysts of floor of the mouth. Am J Otolaryngol 2001;21:55.

25. Blenkinsopp R, Rowe N. Recurrent dermoid cyst of the floor of the mouth. Br J Oral Surg 1980;18:34. 